\title{
Hydrologické modelování srážko-odtokového procesu v povodí Husího potoka
}

\section{JANA UHROVÁ, KAMILA ZÁRUBOVÁ}

\author{
Klíčová slova: povodí Husího potoka - odtok - srážka - srážko-odtokový model - schematizace - HEC-HMS - krajinný pokryv
}

\section{SOUHRN}

Cílem projektu QJ1520268 Nové postupy optimalizace systémů integrované ochrany území v kontextu jejich ekonomické udržitelnosti, který je řešen na pracovišti brněnské pobočky VúV TGM, v. v. i., je vytvoření návrhu systému optimalizace hospodaření s vodními i půdními zdroji v dlouhodobém horizontu, včetně jejich bilancování v systému pưda-rostlina-atmosféra. Současně řešení sleduje omezení dopadů klimatických změn na zemědělské ekosystémy, což je v současnosti velmi aktuální problém. Pro posouzení vlivů konkrétních změn v povodí Husího potoka byl vytvořen srážko-odtokový (S-O) model v programu HEC-HMS, který bude nadále sloužit pro další posuzování reálných návrhů ochranných opatření v ploše povodí i modelových scénáruu využití krajiny. Příspěvek se věnuje popisu vytvoření S-O modelu, který bude dále použit pro posuzování funkčnosti návrhů protierozních a protipovodňových opatření. Prozatím byly testovány tři různé scénáře pokryvu - stávající stav využití území, návrh plošných ochranných opatření na zemědělské pưdě a zatravnění všech ploch vedených $v$ kategorii orná půda.

\section{ÚVOD}

Cílem řešeného projektu je na pilotním území navrhnout komplexní integrovanou ochranu území a řízení vodního režimu se zaměřením na organizaci území a optimální orientaci vývoje zemědělského a lesního hospodaření. Pilotní území - povodí Husího potoka - bylo pro návrh vybráno zejména na základě posouzení povodňového nebezpečí z přivalových srážek, které charakterizují zejména specifické fyzicko-geografické podmínky, pedohydrologické vlastnosti a způsoby uživání území [1]. Vybrané povodí bylo také postiženo katastrofální povodňovou událostí v červnu 2009. Ve městě Fulnek, nacházejícím se ve stredu povodí prímo na Husím potoce, se škody způsobené povodněmi vyšplhaly na částku 297 mil. Kč, v obci Hladké Životice dosáhly škody 17 mil. Kč. Což dohromady prèdstavovalo téměř $10 \%$ z celkových škod vzniklých při události v Moravskoslezském kraji [2]. V povodí se nachází lokality mimořádně silně ohrožované nebezpečnými odtoky z přivalových srážek, které vedou k četným povodňovým situacím, doprovázeným intenzivní vodní erozí a transportem splavenin.

V následujících kapitolách je popsáno vytvoření S-O modelu v programu HEC-HMS (Hydrology Engineering center - Hydrologic modeling system) [3] vyvinutý v US Army Corps of Engineers pro posouzení vlivů konkrétních změn v povodí Husího potoka a možnosti vyhodnocení jejich vlivu na odtokové stavy z povodí. Model byl sestaven pro povodí, kde byla pro kalibraci využita povodňová situace z května 2010 a pro verifikaci posloužila povodňová situace z července 1997. Na vytvořených verifikovaných modelech byly následně provedeny simulace dvou př́znivých scénářů využití území. Při prvním scénári byla na jednotlivých plochách orné půdy navržena plošná ochranná protierozní opatření (organizační a agrotechnická opatření). Druhý scénář počítal se zatravněním všech orných ploch v povodí.

\section{MATERIÁLY A METODA VYTVOŘENÍ HYDROLOGICKÉHO MODELU}

Jediný monitorovaný měrný profil kategorie B (vedený na hlásné a předpovědní povodňové službě ČHMú pod číslem 266, databankové číslo stanice 2511) se záznamem průtoku v hodinovém kroku z požadovaných období výskytu událostí v povodí Husího potoka se nachází na Husím potoce (ř. km 10,36) před vtokem levostranného př́toku Gručovky ve městě Fulnek a je provozován ČHMÚ. Proto bylo pro prvotní srážko-odtokový (S-O) model uvažováno povodí pro závěrový profil ve městě Fulnek, které zaujímá plochu 58,97 km², což je zhruba $41 \%$ celého povodí Husího potoka.

Prvním nezbytným krokem pro vytvoření S-O modelu je schematizace povodí, tj. rozdělení na dílčí povodí, z nichž každé má své specifické vlastnosti. Hlavním vstupem pro schematizaci i stanovení základních vstupních parametrů byl digitální model terénu 4. generace (DMT 4G), získaný od ČÚZK, který zobrazuje upravený zemský povrch v digitálním tvaru ve formě výšek diskrétních bodů v pravidelné síti $(5 \times 5 \mathrm{~m})$ bodů s úplnou střední chybou výšky $0,3 \mathrm{~m}$ v odkrytém terénu a $1 \mathrm{~m}$ v zalesněném terénu. Tato 4 . generace DMT byla vytvořena metodou leteckého laserového skenování, které proběhlo v letech 2009 až 2013. Schematizace byla vytvořena v prostředí GIS za pomoci nástroje HEC-GeoHMS [3], který byl využit ke zpracování DMT, určení rozvodnic a říční sítě, určení finální podoby členění povodí a říční sítě. Zároveň byl použit i pro výpočet některých fyzicko-geografických charakteristik povodí soutokových uzlů a k nim se vztahujících dílčích úseků vodních toků, které tvoří vstupní parametry S-O modelu a jsou uvedeny v tabulce 1. Řešené území bylo rozděleno na 19 dílčích povodí s plochou v rozmezí zhruba 0,15-11 km² (obr. 1).

Do programu HEC-HMS vstupuje schematizované povodí, tj. úseky a jejich charakteristiky (délky, prưměrné sklony, rozměry, drsnosti) a k nim zavěšené plochy a jejich charakteristiky (plocha, sklon aj.) podle zvolených výpočtových metod. Rozměry a drsnosti úseků toků byly stanoveny velice podrobně na základě terénních měření, která proběhla $v$ létě tohoto roku. $V$ rámci těchto měření byly šetřeny jednotlivé typově rozdílné úseky toků tak, aby byly $\checkmark$ každém stanoveném úseku zaměřeny a zmapovány nejméně dva prizmatické úseky. Došlo tak k vytvoření podrobné databáze informací o stavu tokư v povodí Husího potoka a stanovení vypovídajících charakteristik pro každý úsek. Pro výpočet jednotlivých komponentů odtoků je v HEC-HMS na výběr několik metod. Pro naše podmínky byla pro výpočet zvolena metoda SCS CN, 


\section{Dílčí povodí}

\begin{tabular}{|c|c|c|c|c|c|c|c|c|c|c|c|}
\hline $\begin{array}{l}\text { Ozn. } \\
\text { povodí }\end{array}$ & $\begin{array}{l}\text { Plocha } \\
\text { dílčího } \\
\text { povodí } \\
{\left[\mathrm{km}^{2}\right]}\end{array}$ & $\begin{array}{l}\text { CN } \\
\text { povodí [-] }\end{array}$ & $\begin{array}{l}\text { Prům. } \\
\text { sklon } \\
{[\%]}\end{array}$ & $\begin{array}{l}\text { Čas } \\
\text { koncentrace } \\
\text { Tc [hod] }\end{array}$ & $\begin{array}{l}\text { Podíl } \\
\text { neprop. } \\
\text { ploch } \\
{[\%]}\end{array}$ & $\begin{array}{l}\text { Ozn. } \\
\text { úseku }\end{array}$ & $\begin{array}{l}\text { Šířka } \\
\text { ve dnè } \\
\text { b [m] }\end{array}$ & $\begin{array}{c}\text { Sklon } \\
\text { svahů } \\
1: m\end{array}$ & $\begin{array}{l}\text { Drsnostní } \\
\text { součinitel } \\
\text { n [-] }\end{array}$ & $\begin{array}{l}\text { Délka } \\
{[\mathrm{m}]}\end{array}$ & $\begin{array}{l}\text { Podélný } \\
\text { sklon [-] }\end{array}$ \\
\hline W200 & 11,154 & 74,28 & 6,44 & 3,57 & 4,22 & R10 & 1,5 & 1,0 & 0,048 & 6057,70 & 0,0132 \\
\hline W210 & 6,556 & 65,11 & 11,64 & 2,50 & 3,36 & R60 & 1,1 & 2,0 & 0,072 & 4188,17 & 0,0260 \\
\hline W220 & 2,168 & 63,60 & 10,47 & 0,82 & 0,56 & R40 & 1,7 & 0,7 & 0,096 & 916,08 & 0,0379 \\
\hline W230 & 2,423 & 62,44 & 9,44 & 0,89 & 0,45 & R20 & 0,9 & 1,2 & 0,075 & 940,08 & 0,0276 \\
\hline W240 & 0,822 & 54,57 & 12,36 & 0,29 & 0,00 & R30 & 1,9 & 0,8 & 0,080 & 218,99 & 0,0222 \\
\hline W250 & 2,862 & 66,29 & 15,57 & 1,66 & 2,45 & R50 & 2,1 & 1,2 & 0,046 & 3220,28 & 0,0147 \\
\hline W260 & 4,371 & 70,14 & 10,91 & 1,58 & 7,77 & R80 & 1,6 & 1,5 & 0,079 & 2718,64 & 0,0331 \\
\hline W270 & 1,113 & 60,87 & 17,79 & 1,10 & 0,32 & $\mathrm{R} 120$ & 3,5 & 1,0 & 0,061 & 1741,10 & 0,0130 \\
\hline W280 & 2,139 & 59,89 & 9,64 & 0,71 & 0,00 & R70 & 1,2 & 0,6 & 0,078 & 676,05 & 0,0276 \\
\hline W290 & 0,469 & 79,27 & 10,39 & 0,62 & 5,05 & R90 & 2,1 & 0,7 & 0,079 & 1081,90 & 0,0249 \\
\hline W300 & 3,189 & 71,86 & 10,71 & 0,94 & 8,49 & R100 & 1,2 & 1,0 & 0,062 & 1488,22 & 0,0334 \\
\hline W310 & 6,638 & 70,85 & 10,69 & 1,58 & 0,60 & R150 & 0,8 & 1,1 & 0,068 & 2674,82 & 0,0212 \\
\hline W320 & 0,151 & 76,70 & 9,50 & 0,40 & 24,39 & $\mathrm{R} 110$ & 1,2 & 1,4 & 0,048 & 571,13 & 0,0178 \\
\hline W330 & 1,546 & 74,36 & 10,59 & 1,04 & 15,46 & R140 & 1,8 & 1,1 & 0,052 & 1819,59 & 0,0086 \\
\hline W340 & 4,320 & 68,28 & 12,21 & 1,13 & 0,00 & $\mathrm{R} 130$ & 1,4 & 1,1 & 0,070 & 1801,56 & 0,0188 \\
\hline W350 & 3,462 & 72,90 & 14,30 & 0,76 & 24,31 & R160 & 4,4 & 1,0 & 0,032 & 1394,87 & 0,0067 \\
\hline W360 & 1,125 & 70,99 & 15,60 & 0,84 & 24,40 & R180 & 3,2 & 1,0 & 0,048 & 1614,18 & 0,0087 \\
\hline W370 & 1,022 & 73,01 & 15,09 & 0,60 & 2,69 & $\mathrm{R} 170$ & 3,6 & 0,6 & 0,058 & 1079,83 & 0,0101 \\
\hline W380 & 3,031 & 72,90 & 12,73 & 0,18 & 6,01 & R190 & 1,7 & 1,4 & 0,078 & 218,14 & 0,0347 \\
\hline
\end{tabular}

a tedy dalšími definovanými parametry plochy dílčích povodí byly průměrné hodnoty čísla odtokových křivek (CN - Curve Number), čas koncentrace $T_{c^{\prime}}$ podíl nepropustných ploch a počáteční ztráty.

Většina vstupních ukazatelů byla stanovena $v$ prostředí GIS za pomoci nástrojů Geo-HMS a Spatial Analyst. Pracovní postup stanovení čísel CN v prostředí GIS spočivá v sestrojení vektorové vrstvy kombinující vrstvu HSP a vrstvu využití území. Jednotlivým vzniklým kombinacím HSP a využití území byly prirǐazeny konkrétní hodnoty čísla CN čerpané z metodického postupu Ochrana zemědělské půdy pred erozí [4]. Hodnoty CN reprezentují vlastnosti povodí - půdní poměry, využití území (tabulka 2) a předchozí vláhové podmínky. Důležitým faktorem z hlediska tvorby odtoku a tedy i retence povodí je také nasycenost povodí pred povodňovou událostí. Předchozí vlhkosti půdy určované na základě pětidenního úhrnu prededcházejících srážek, resp. indexu předchozích srážek (IPS) na IPS II. 


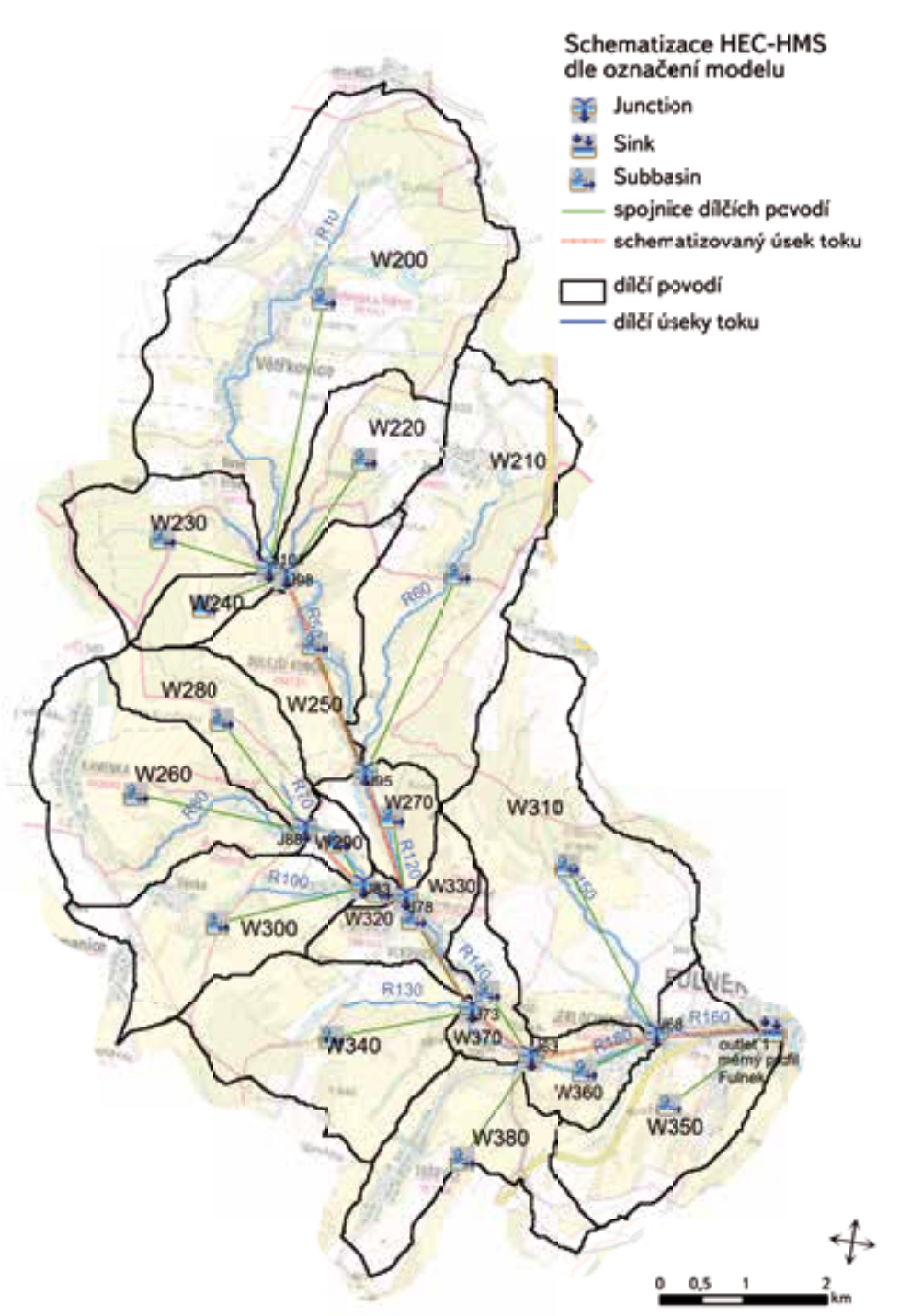

Obr. 1. Schematizace pro HEC-HMS

Fig. 1. Schematization to HEC-HMS

Tabulka 2. Podil kultur při současném využití krajinného pokryvu v povodi Table 2. Actual land use in the basin

\section{Název kultury LPIS}

\begin{tabular}{lr}
\hline rychle rostoucí dřeviny & 73040,1 \\
\hline travní porost (na orné půdě) & 826381,0 \\
\hline jiná trvalá kultura & 2556,0 \\
\hline školka & 6839,6 \\
\hline
\end{tabular}

\begin{tabular}{lr}
\hline zalesněná půda & 148128,7 \\
\hline jiná kultura & 349,7 \\
\hline standardní orná půda & 15564650,6 \\
\hline ovocný sad & 29311,5 \\
\hline
\end{tabular}

trvalý travní porost

úhor

18085022,6

66260,6
Volba metody transformace prímého odtoku je klíčovou součástí metodického postupu, nebot prímo určuje tvar viny, a tím i velikost kulminačního průtoku. V této práci byl využit jednotkový hydrogram podle Clarka (Clark unit hydrograph). S ohledem na stanovenou metodu výpočtu SCS CN byl čas koncentrace T vypočitán podle vzorce SCS (Soil Conservation service) (rovnice 2), vycházející z $T_{\text {LAG }}$ (rovnice 1), což je časový posun v hodinách mezi výskytem maxima prričinné srážky a výskytem kulminačního průtoku v počítaném závěrovém profilu [5].

$$
T_{L A G}=\frac{\left(3,281 \cdot L^{0,8} \cdot(0,0394 \cdot A+1)^{0,7}\right.}{(1900 \cdot \sqrt{Y)}}
$$

kde $L \quad$ je délka údolnice $[\mathrm{m}]$,

A potencionální retence povodí vyjádřená pomocí CN křivek [mm] (rovnice 3),

Y $\quad$ průměrný sklon povodí [\%].

$$
\begin{aligned}
& T_{C}=1,67 \cdot T_{\text {LAG }} \\
& A=25,4\left(\frac{1000}{C N}-10\right)
\end{aligned}
$$

Pro výpočet podzemního odtoku byla využita recesní metoda (recession) a odtok v korytě byl stanoven s využitím metody Muskingum-Cunge. Metoda je založena na aproximaci kombinace rovnice kontinuity a difuzní formy momentové rovnice [6] a podrobněji je popsána např. [7].

Základem odtoku velkých vod, potažmo prírozené retence povodí jsou srážky, které jsou do modelu zadávány ve formě časové řady (hyetogramu). Pro stanovení charakteristik využitých příčinných deštů (tabulka 3) bylo využito dat pozemních srážkoměrných stanic Mošnov a Vítkov provozovaných ČHMú.

Pro kalibraci byla použita časová rada srážek ze stanice Mošnov a průtoků v profilu Fulnek v období 27. května 2010 (12:00)-29. května 2010 (23:00) a pro verifikaci pak událost, která proběhla v období 6. července 1997 (0:00)-9. července 1997 (23:00), zde byla použita časová řada srážek ze stanice Vítkov. V obou prípadech byly dosazeny hodnoty $v$ hodinovém kroku.

Tyto dva příčinné deště byly vybrány z několika řad měřených dat, které byly z důvodu řady nekvalit či nepoužitelnosti současně s daty odtokovými, jako základní vstupní data, vyloučeny. Rozpory mezi odtokovými daty a daty ze srážkoměrných stanic (zejména nepromítnutí srážek do odtoku či naopak) jsou způsobeny zejména velkou vzdáleností srážkoměrných stanic od měrného profilu Fulnek. Stanice Vítkov se nachází ve vzdálenosti zhruba 12,74 km a stanice Mošnov (na Mezinárodním letišti Leoše Janáčka) ve vzdálenosti 14,73 km vzdušnou čarou.

Pro posouzení shody modelovaného a měřeného hydrogramu v závěrovém profilu S-O modelu bylo použito Nash-Suttcliffe kritérium E [8] (rovnice 4), které je pravděpodobně nejpoužívanějším kritériem při hodnocení hydrologických modelů.

$$
E=1-\frac{\left(\sum_{i=1}^{n}\left(Q_{O B i}-Q_{S I M i}\right)^{2}\right.}{\left(\sum_{i=1}^{n}\left(Q_{O B i}-\bar{Q}_{O B}\right)^{2}\right.}
$$

kde $Q_{O B i}$ je pozorovaný průtok pro daný časový krok $\left[\mathrm{m}^{3} / \mathrm{s}\right]$,

$$
\begin{array}{ll}
Q_{S I M i} & \text { simulovaný průtok pro daný časový krok }\left[\mathrm{m}^{3} / \mathrm{s}\right], \\
\bar{O}_{O B} & \text { průměrný pozorovaný průtok pro celou časovou řadu }\left[\mathrm{m}^{3} / \mathrm{s}\right] .
\end{array}
$$


Tabulka 3. Charakteristiky využitých příčinných deštư

Table 3. Characteristics of casual rain

\section{Období}

povodňové události

\section{Srážkoměrná} stanice

\section{Délka trvání deště td [min]}

\section{Celkový úhrn deště $\mathrm{Hs}$ [mm]}

\author{
Intenzita \\ příčinného deště \\ id [mm. $\left.\mathrm{min}^{-1}\right]$
}

\begin{tabular}{|c|c|c|c|c|c|}
\hline 1997 & Vítkov & 4620 & 234,6 & 0,0508 & 44,1 \\
\hline 2010 & Mošnov & 360 & 4,7 & 0,0131 & 5,1 \\
\hline
\end{tabular}

Pokud platí kritérium shody $E=1$, jedná se o absolutní shodu. Když je $E \geq 0,5$, jedná se o uspokojivou shodu, a pokud je $\mathrm{E}<0,5$ (může nabývat hodnot až do - $\infty$ ), pak jde o neuspokojivou shodu a simulovaný hydrogram není dostatečně kvalitní.

Na verifikovaných modelech byly následně provedeny simulace dvou příznivých scénářu využití území, které byly reprezentovány predevším změnou parametrů CN. První scénář spočíval v návrhu tzv. organizačních a agrotechnických opatření na zemědělsky využívané pưdě, návrh byl proveden se zaměřením na ochranu půdy pred projevy vodní eroze (obr. 2). Z celkové plochy $34,7 \mathrm{~km}^{2}$ orné půdy bylo navrženo na cca 35,4\% plošné ochranné opatření. Vyloučení pěstování erozně nebezpečných plodin je navrženo na 17,2 \% orné půdy, tedy že půda bude osázena úzkořádkovými plodinami dostatečně kryjící povrch půdy v období výskytu přivalových srážek. A dále byla navržena agrotechnická opatření na cca 13,3\% orné půdy s ponecháváním posklizňových zbytků, s předpokladem dobrých hydrologických podmínek. K trvalému zatravnění je navrženo 4,9\% orné půdy. Druhý scénář spočíval v zatravnění veškeré orné půdy, cca $46,1 \%$ plochy povodí.

\section{DOSAŽENÉ VÝSLEDKY A DISKUSE}

Cílem hydrologického modelování je vytvořit takový srážko-odtokový model, který by se co nejvíce blízil skutečnému chování povodí, tedy skutečným měěeným průtokům. Toho Ize dosáhnout optimalizací vhodných parametrů popisujících systém právě při procesu kalibrace a ověřením kalibrovaného modelu $\checkmark$ procesu verifikace.

\section{Kalibrace modelu}

Pro kalibraci byla použita časová řada srážek ze stanice Mošnov a průtoků v profilu Fulnek z května 2010 s hodinovým krokem s dosaženým kulminačním průtokem $5,1 \mathrm{~m}^{3} / \mathrm{s}$.

$\checkmark$ rámci ruční kalibrace byly kalibrovány tyto parametry:

- počáteční ztráta (Initial abstraction) [mm],

- číslo CN (Curve number) [-],

- zásobní koeficient (storage coefficient) [h],

- čas koncentrace (time of concentration) [h],

- recesní konstanta (recession constant) [-],

- konstanta ratio to peak [-].

Po kalibraci byla provedena automatická optimalizace s maximálním počtem iterací 100 pro zpřesnění kalibrovaných hodnot. Kalibrované hodnoty byly optimalizacízprěesněny, změny těchto parametrů se pohybovaly $v$ průměru rádově $v$ jednotkách \%, pro čísla CN byl vyhodnocen index změny roven jedné, tedy beze změny.

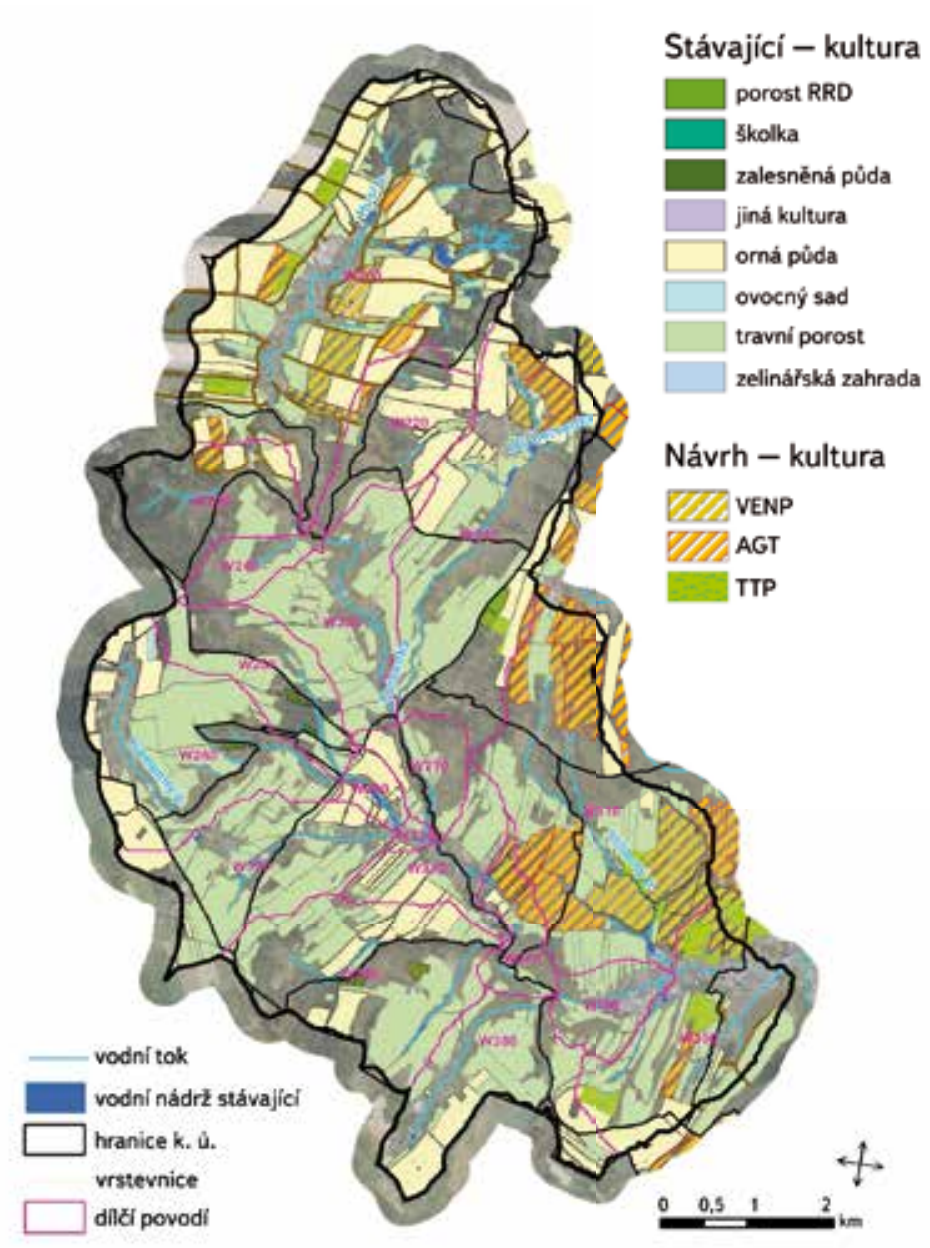

Obr. 2. Variantní návrh plošných protierozních opatření v povodí Husího potoka (VENP vyloučení erozně nebezpečných plodin, AGT - agrotechnická opatření, TTP - trvalý travní porost)

Fig. 2. Variant designing of erosion control measures in "Husí potok" basin (VENP exclusion of dangerous erosion crops, AGT - agro-technical measures, TTP - permanent grassland) 
stanice Mošnov, ze které byly použity srážky, se nachází mimo povodí Husího potoka ve vzdálenosti téměř $15 \mathrm{~km}$ od měrného profilu ve Fulneku. Nepřesnost může způsobit také zvolená metoda SCS, tato rozkolísanost bude v budoucnu podrobena analýze. I pres vyšší vypočítaný kulminační průtok $\left(54,0 \mathrm{~m}^{3} / \mathrm{s}\right)$ oproti skutečně naměřenému o zhruba $17 \%$ je vypočítaný objem povodně pouze o 0,2 \% nižší. Objem povodně je pro naše stanovení zásadní kritérium. Proto byla i verifikace považována za prijiatelnou a tento model, zejména jeho hodnoty kalibračních koeficientů a kalibrovaných parametrů, se stane při následném modelování vstupem pro simulování vlivu stávajících i navrhovaných ochranných opatření v povodí.

\section{VÝSLEDKY SIMULOVANÝCH SCÉNÁŘŮ KRAJINNÉHO POKRYVU}

Na verifikovaných modelech byly následně provedeny simulace dvou přiznivých scénárư využití území, které byly aplikovány do obou namodelovaných událostí (květen 2010 a červenec 1997). Pro další analýzy byla vybrána událost z července 1997, kde byl význam krajinného pokryvu na odtokové charakteristiky výraznější podle rozdílů zaznamenaných v kulminaci i objemu povodně (obr. 5).

Prvním simulovaným scénářem byl návrh plošných ochranných opatření (vyloučení erozně nebezpečných plodin, použití agrotechnologických postupů a návrh na částečné trvalé zatravnění) (obr. 2). Návrhem došlo ke snížení hodnot $C N \vee$ dílčích povodích v průměru o 0,6 \% (maximálně o 3,7 \%), což mělo za následek pouze nepatrné snížení kulminačního průtoku i objemu povodně. Maximální kulminační průtok byl oproti simulovanému snížen z hodnoty $54,0 \mathrm{~m}^{3} / \mathrm{s}$ na $53,2 \mathrm{~m}^{3} / \mathrm{s}$. Došlo tedy $\mathrm{k}$ jeho snížení o 1,5\%. Objem povodně by $v$ prípadě aplikace návrhů PEO v povodí v uvažovaném rozsahu byl snížen o 1,7 \% z hodnoty $8660700 \mathrm{~m}^{3}$ na $8516900 \mathrm{~m}^{3}$, přičemž objem skutečné měřené povodně činil $8529300 \mathrm{~m}^{3}$.

Druhým simulovaným scénářem byl návrh trvalého zatravnění na všech plochách orné půdy. Aplikací došlo k výraznějšímu snížení hodnot CN v dílčích povodích, v prüměru o 4,2 \% (maximálně o 12,6\%). Při tomto scénáři došlo již k patrnějšímu snížení maximálního kulminačního průtoku i objemu povodňové vlny. Maximální kulminační průtok byl oproti simulovanému snížen z hodnoty $54,0 \mathrm{~m}^{3} / \mathrm{s}$ na $49,8 \mathrm{~m}^{3} / \mathrm{s}$, tedy došlo ke snížení o $7,8 \%$. Objem povodně by byl $\checkmark$ prípadě aplikace ochrany ploch orné půdy formou zatravnění snížen o 8,7 \% z hodnoty $8660700 \mathrm{~m}^{3}$ na $7906000 \mathrm{~m}^{3}$.

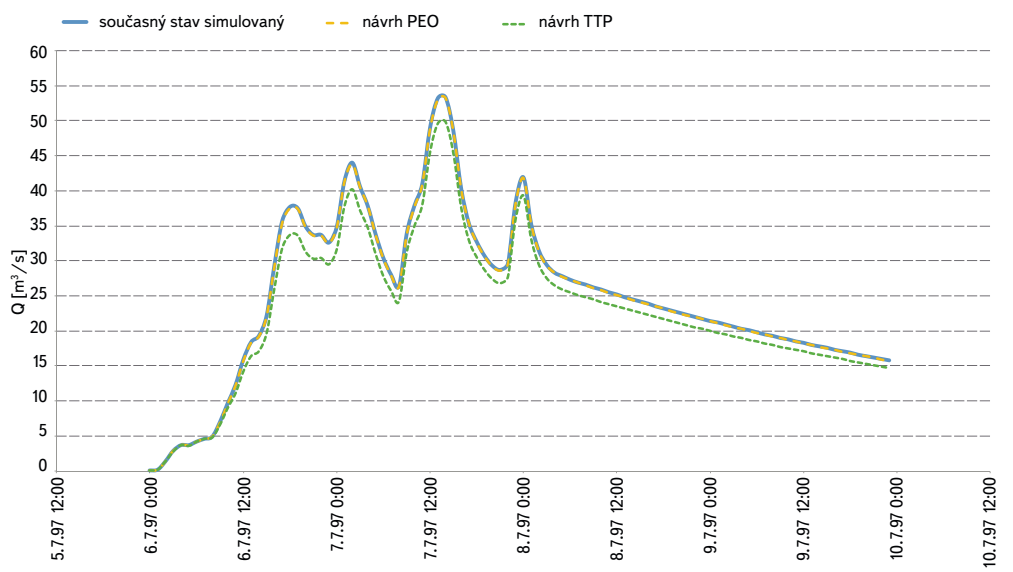

Obr. 5. Porovnání hydrogramů odtoku v závěrovém profilu při variantním využití území pro srážkovou událost z července 1997

Fig. 5. Comparison of hydrographs in the outfall with two variants in land use (precipitation July 1997) (blue - simulated, yellow - agrotechnical and organizational erosion control measures, green - grassland on all agricultural soil)

\section{ZÁVĚR}

Velkým problémem u takto malých povodí, jako je povodí Husího potoka, je častá absence podrobného měření proběhlých srážko-odtokových událostí, což je částečně prípad i povodí Husího potoka. V povodí se sice nachází měrný profil se záznamem průtoků ve městě Fulnek, chybí však měření průtoků tokem těsně před jeho zaústěním do Odry a srážkoměrná stanice $s$ dlouhodobým záznamem dat umístěná prímo v povodí. Až v rámci řešení projektu QJ1520268 byl v povodí Husího potoka rozšířen monitorovací a informační systém (MIS) o 4 nevyhřivané srážkoměry a 4 hladinoměry pro získání dat přímo z povodí. S ohledem na měrný profil byl vytvořen hydrologický model v programu HEC-HMS jen pro část povodí Husího potoka nad profilem, na kterém byly vyhodnoceny dvě srážko-odtokové epizody v různých časových obdobích (z července 1997 a května 2010). Popsanou kalibrací a verifikací byl vytvořen prvotní odhad kalibračních veličin, které budou dále zpřesňovány. Budou následovat práce, jejichž cílem bude další zpřesňování modelu, zaměřené zejména na větší podrobnost schematizace. Při jemnější schematizaci dojde ke zpřesnění vstupních charakteristik dílčích povodí i úseků toků. Poté bude provedena nová kalibrace a verifikace, kde bude pravděpodobně zakomponována událost z června 2009, která je svým úhrnem a charakterem více podobná události z května 2010, na kterou byl model kalibrován. Tím by mělo dojít ještě ke zpřesnění jak vstupních, tak i kalibrovaných charakteristik a tento model se poté stane výchozím modelem pro celé povodí Husího potoka.

Na vytvořeném prvotním modelu byly dále simulovány scénáře změn krajinného pokryvu formou návrhu plošných ochranných opatření proti vodní erozi půdy na orné půdě (agrotechnická a organizační opatření a návrh TTP) pro zjištění vlivu způsobu využití území v povodí. Z dosažených výsledků je patrné, že pouze změna krajinného pokryvu není dostatečnou protipovodňovou ochranou pro snížení kulminačního průtoku při typově podobných srážkových událostech, jaké byly na území aplikovány.

Při srážko-odtokovém modelování je také třeba počítat s tím, že jak do výpočtů vstupních parametrů, tak i následně do samotného modelu vstupuje řada nejistot a nepřesností. Chyby v měření průtoků při měření vodního stavu jsou asi $1 \mathrm{~cm}$ a hlavní zdroj nejistoty nastává při převodu naměřených vodních stavů na průtokové veličiny. U měřených srážkových dat může mít např́iklad velký vliv působení větru (2-15\%) a další náhodné i systematické chyby. Celkově se tedy chyby $v$ měření pohybují okolo 10-15\% [10].

I přesto Ize s ohledem na Nash-Suttcliffe kritérium „E“ považovat kalibrované a následně verifikované modely povodí za dostatečně vypovídající a funkční, aby se jejich parametry mohly stát zdrojem pro vytvoření jemnějšího modelu a dále modelu pro celé povodí Husího potoka. Ten pak bude podroben následnému hodnocení funkčnosti a míry transformace povodně pro další návrhové stavy využití krajiny i návrhy nových vodních nádrží jako zásadnějších prvků pro zadržení a zpomalení odtoku, které jsou v rámci projektu plánovány. Parametry odtoku z celého povodí Husího potoka v místě, kde se vlévá do Odry, budou následně stanoveny právě hydrologickým modelováním na stanovený model.

\section{Poděkování}

Př́spěvek vznikl za podpory projektu QJ1520268 Nové postupy optimalizace systémů integrované ochrany území v kontextu jejich ekonomické udržitelnosti řš̌eného $\checkmark$ rámci programu KUS Ministerstva zemědělství ČR. 


\section{Literatura}

[1] DRBAL, K. Implementace směrnice EU o vyhodnocováni a zvládáni povodňových rizik. Brno: VúVTGM, 2010.

[2] DRBAL, K. aj. Vyhodnocení povodní v červnu a červenci 2009 na území České republiky, DỦ Metodika mapování povodňového rizika. Brno: VúV TGM, 2009

[3] HEC - Hydrologic Engineering Center. US Army Corps of Engineers [online]. 2010 [cit. 2010-06-13]. Dostupné z: http://www.hec.usace.army.mil/

[4] JANEČEK, M. aj. Ochrana zemědělské půdy pred erozí: Metodika. Praha: ČZU, 2012 ISBN 978-80-87451-42-9.

[5] DINGMAN, S.L. Physical Hydrology, 2nd. ed. Upper Saddle river:Prentice Hall. 2002. ISBN 0-13-099695-5.

[6] ŠERCL, P. Vliv Fyzicko-geografických faktorů na charakteristiky teoretických návrhových povodñových vin. Praha, 2009. ISBN 978-80-86690-62-9.

[7] FELDMAN, A.D. (Ed.). Hydrologic Modeling System HEC-HMS Technical Reference Manual. US Army Corps of Engineers. Washington, 2000.149 s. Dostupný z www: http://www.hec.usace.army.mil/ software/hec-hms/documentation.html.

[8] JENIĆEKE, M. Modelování prüběhu extrémnich povodni v kontextu krajinných změn a integrované protipovodñové ochrany. Praha, 2009.

[9] ČHMú. Hlásná a predpovědní povodňová služba [online]. 2016 [cit. 2016-09-20]. Dostupné z: http:// hydro.chmi.cz/hpps/hpps_main.php

[10] ČHMÚ. Využití údajů o historických povodnich pro účely hydroprognózy, Tomáš Vlasák (ČHMú České Budějovice). Katalog prezentací [online]. 2016 [cit. 2016-09-29]. Dostupné z: http://portal.chmi.cz/ files/portal/docs/poboc/CB/katalogprezentaci/files/prezentace_prednaska_uk_historicke_rady_ zmensene_obrazky.ppt.

\section{Autoři}

Ing. Jana Uhrová, Ph.D.

凶jana_uhrova@vuv.cz

\section{Ing. Kamila Zárubová}

凶kamila_zarubova@vuv.cz

Výzkumný ústav vodohospodářský T. G. Masaryka, v. v. i.

Přispěvek prošel lektorským řízením.

\section{HYDROLOGICAL MODELING OF PRECIPITATION-RUNOFF PROCESS IN THE "HUSÍ POTOK" BASIN}

\section{UHROVA, J.; ZARUBOVA, K.}

TGM Water Research Institute, p. r. i.

Keywords: runoff - precipitation - precipitation-runoff model - schematization - HEC-HMS - land use

The aim of the project "QJ1520268 The new procedures of optimization systems integrated protection area in the context of their economic sustainability" is to create a design optimized system of management of water and soil resources in the long term, including balancing the soil-plant-atmosphere system and also in order to reduce the impact of climate change on agricultural ecosystem, which is highly topical issue today. To assess the effects of specific changes in the "Husi potok" basin the runoff model in HEC-HMS was created and this model will be used for further assessment. This article describes the creation of runoff model in HEC-HMS, including calibration, optimalization and verification and simulation of two different ways of land use. First simulated variant of land use was application of agro-technical and organizational erosion control measures. Second simulated variant of land use was application of grassland on all agricultural soil. These models demonstrate that change of land use could affect the characteristics of flood - peak flow and flood volume, but not enough (see Fig. 5). That is the reason to design the complex and strategic solutions around the "Husí potok" basin for all area of the basin and not just a local solution in individual cadastre. There is only one flow measurement in "Husí potok" basin in Fulnek city, so the hydrological model was created for this outlet. The subbasin to outlet in Funek is about $41 \%$ of all "Husí potok" basin. Another problem is absence of weather station in the basin. We took data from weather station Vítkov (12.74 km from Fulnek) and Mošnov (14.74 km from Fulnek). These big distances are one of the reasons, why the shape of flood is not 100\% (see Fig. 3 and 4). However, due to Nash-Sutcliffe model efficiency coefficient, which was 0.933 (calibration) and 0.854 (verification), the model was found sufficient for further use. Characteristics from this created and tested hydrological model will be used for a full basin model. 